\title{
PERAN EFIKASI DIRI DAN DUKUNGAN SOSIAL TEMAN SEBAYA TERHADAP BELAJAR BERDASAR REGULASI DIRI PADA MAHASISWA UNIVERSITAS ISLAM SULTAN AGUNG SEMARANG
}

\author{
Heni Ratna Sari dan Ruseno Arjanggi \\ Fakultas Psikologi Universitas Islam Sultan Agung, Jalan Kaligawe Raya KM. 4, Semarang \\ Email: ruseno@unissula.ac.id
}

\begin{abstract}
Abstrak
Penelitian ini bertujuan untuk mengetahui peran efikasi diri dan dukungan sosial teman sebaya terhadap belajar berdasar regulasi diri pada mahasiswa Universitas Islam Sultan Agung Semarang. Penelitian ini menggunakan metode kuantitatif korelasional. Populasi dalam penelitian ini adalah mahasiswa Universitas Islam Sultan Agung Semarang. Sampel penelitian ini berjumlah 150 mahasiswa Universitas Islam Sultan Agung Semarang. Metode pengambilan sampel menggunakan simple random sampling. Alat ukur yang digunakan dalam penelitian ini terdiri dari tiga skala. Skala belajar berdasar regulasi diri berjumlah 68 aitem yang memiliki koefisien reliabilitas 0,941 dengan indeks daya beda aitem bergerak antara 0,277 sampai 0,683. Skala efikasi diri berisi 30 aitem yang memiliki koefisien reliabilitas 0,896 dengan indeks daya beda aitem yang bergerak antara 0,256 sampai 0,693 . Serta skala dukungan sosial teman sebaya berisi 40 aitem yang memiliki koefisien reliabilitas 0,919 dengan indeks daya beda aitem yang bergerak antara 0,301 sampai 0,726. Analisis data menggunakan analisis regresi ganda dan parsial. Hasil penelitian menunjukskan adanya peran positif efikasi diri dan dukungan sosial teman sebaya terhadap belajar berdasar regulasi diri dengan diperoleh skor $\mathrm{R}=0,325$ dan $F_{\text {hitung }}=8,665, p=0,000(p<0,05)$. Variabel efikasi diri dan dukungan sosial teman sebaya secara bersamaan memiliki sumbangan efektif sebesar 10,5\% terhadap variabel belajar berdasar regulasi diri. Uji korelasi parsial efikasi diri dengan belajar berdasar regulasi diri diperoleh skor $r_{x 1 y}=0,178$ dengan signifikan $0,030(p<0,05)$. Hasil tersebut menunjukkan adanya peran positif efikasi diri terhadap belajar berdasar regulasi diri. Uji korelasi parsial dukungan sosial teman sebaya dengan belajar berdasar regulasi diri diperoleh skor $r_{x 2 y}=0,173$ dengan signifikan $0,035(p<0,05)$. Hasil tersebut menunjukkan adanya peran positif dukungan sosial teman sebaya terhadap belajar berdasar regulasi diri.
\end{abstract}

Kata Kunci: Belajar Berdasar Regulasi Diri, Efikasi Diri, Dukungan Sosial Teman Sebaya

\section{THE ROLE OF SELF EFFICACY AND PEERS SOCIAL SUPPORT TO LEARN BASED ON SELF REGULATION ON STUDENTS OF SULTAN AGUNG ISLAMIC UNIVERSITY SEMARANG}

\begin{abstract}
This research intended to know the role self-efficacy and peers social support in learning based on self regulation on students of Islamic University of Sultan Agung Semarang. This research used the correlational quantitative method. The population of this research were the students of Islamic University of Sultan Agung Semarang. There were 150 students of Islamic University of Sultan Agung Semarang as the sample. The method to collecting the sample was simple random sampling. Measuring instrument which is used in this research up for three scales. Learning scale based on self regulation were 68 items that have reliability coefficient 0,941 with different items power index moving beetwen 0,277 to 0,683. Self efficacy scale consisted 30 items that have reliability coefficient 0,896 with different items power index moving beetwen 0,256 to 0,693. As well as the peers social support scale consisted 40 items that have reliability coefficient 0,919 with different
\end{abstract}


items power index moving beetwen 0,301 to 0,726. The data analysis used multiple regression analysis and paetial correlation. The result showed that role self efficacy and peers social support to learn based on selfregulation, $R$ score was 0,325 and $F_{\text {sig }}=8,665, P=0,000(p<0,05)$. The self efficacy variable and peers social support at the same time has 10,5\% effective contribution toward variable of learning based on self regulation. The result of correlation partial test self efficacy and learning based self regulation obtained score $r_{x 1 y}=0,178$ which was the significant $0,030(p<0,05)$. The result of correlation partial test showed a positive role self efficacy of learning based on self-regulation. The result of correlation partial test peers social support and learning based on self-regulation obtained score $r_{x 2 y}=0,173$ which was the significant $0,035(p<0,05)$. The result of correlation partial test showed a positive role peers social support of learn based on self-regulation.

Keywords: Learn based on self-regulation, self efficacy, peers social support.

\section{PENDAHULUAN}

Pengembangan di bidang pendidikan terus meningkat dengan seiring berkembanganya zaman. Upaya yang dapat digunakan dalam mengembangkan kualitas sumber daya manusia salah satunya dengan pendidikan. Pendidikan memegang peran yang cukup penting dalam membentuk sumber daya manusia yang berkualitas. Kemampuan belajar individu dalam perguruan tinggi menjadi salah satu cara dalam mengembangkan kualitas sumber daya manusia. Kemampuan inilah yang akan membawa dampak meningkatnya sumber daya manusia.

Selama menempuh pendidikan di perguruan tinggi, mahasiswa terus menetapkan tujuan dan akan menghadapi beberapa tantangan untuk berhasil menyelesaikan karir mereka. Memiliki kemampuan dan kompetensi saja tidak cukup untuk mencapai tujuan akademik. Pengaturan diri dalam pendidikan sangat dibutuhkan dimana pengaturan diri digunakan sebagai sumber daya individu untuk merencanakan dan mengendalikan proses belajar.

Kemampuan mahasiswa mengontrol diri dalam belajar memiliki peran yang cukup penting untuk mencapai kesuksesan pembelajaran di perguruan tinggi. Individu yang menjadi pengatur sendiri atas proses pembelajaran mereka akan berdampak pada kesuksesan akademis (Labuhn, Zimmerman, \& Hasselhorn, 2010). Belajar berdasar regulasi diri mengacu pada sejauh mana individu berperan dalam motivasi, metakognisi serta perilaku dalam kegiatan belajar (Zimmerman, 2008).

Perguruan tinggi tidak hanya menuntut mahasiswa mampu menyerap ilmu yang diterima dalam perkuliahan, namun diharapkan mampu mengembangkan potensi yang mereka dapatkan dalam perkuliahan. Keberhasilan mahasiswa dipengaruhi oleh seberapa besar keyakinan diri untuk berhasil. Kepercayaan diri yang tinggi dan dorongan dari lingkungan mampu membantu mereka untuk mencapai keberhasilan yang lebih optimal.

Butler \& Winne (Effeney, Carroll, \& Bahr, 2013) mahasiswa seharusnya bersikap mandiri dan aktif dalam menentukan tujuan, memutuskan rencana yang tepat, dan menargetkan waktu mereka. Faktanya kebanyakan mahasiswa masih melakukan proses pembelajaran tanpa didasari adanya perencanaan, kontrol, pengamatan serta penilaian kembali proses pembelajaran. Hal tersebut membuat mahasiswa sering menunda-nunda menyelesaikan tugas, mengerjakan tugas asal-asalan, mengumpulkan tugas telat, terlambat kuliah, kurangnya perhatian saat perkuliahan dan belajar hanya ketika menghadapi ujian. Kurang adanya pengontrolan dari lingkungan juga menyebabkan mahasiswa tidak mampu melakukan proses belajar dengan baik. Fakta inilah yang menunjukkan bahwa mahasiswa kurang memiliki kemampuan meregulasi diri dalam proses belajar. 
Zimmerman (2013) mendefinisikan belajar berdasar regulasi diri yaitu individu berperan aktif secara motivasi, metakognitif serta perilaku dalam proses pembelajaran untuk mencapai tujuan pembelajaran. Belajar berdasar regulasi diri dilakukan secara aktif dan konstruktif dimana individu menyesuaikan pikiran, perasaan dan tindakan mereka yang dibutuhkan untuk memengaruhi pembelajaran dan motivasi mereka (Boekaerts \& Corno, 2005). Cheng (2011) mendefinisikan bahwa belajar berdasar regulasi diri adalah kegiatan dengan melibatkan pikiran, emosi, tindakan serta lingkungan individu. Selain itu seorang guru diperlukan dalam memberi saran kepada siswa tentang penilaian diri, motivasi, penetapan tujuan dan strategi pembelajaran, serta pemantauan.

Belajar berdasar regulasi diri merupakan proses proaktif dimana individu memperoleh keterampilan akademik dengan menetapkan tujuan, memilih dan menerapkan strategi serta pemantauan sendiri proses pembelajaran (Zimmerman, 2008b). Belajar berdasar regulasi diri adalah strategi atau metode yang digunakan pembelajar untuk mencapai tujuan pembelajaran. Belajar berdasar regulasi diri mengacu pada pemikiran, perasaan dan perasaan yang dihasilkan tindakan sendiri untuk mencapai tujuan pembelajaran individu (Zimmerman \& Moylan, 2009). Belajar berdasar regulasi diri secara efektif mengatur kognisi dan motivasi mereka untuk menyesuaikan diri dengan tuntutan tugas, sumber daya dan tujuan yang ditetapkan (Marzouk et al., 2016)

Clark \& Zimmerman (2014) mengungkapkan bahwa belajar berdasar regulasi diri dipengaruhi oleh tiga hal yaitu pribadi, perilaku serta lingkungan. Faktor individu yaitu kemampuan, pengetahuan, tujuan dan efikasi diri. Faktor perilaku yaitu perilaku reaksi diri, reaksi diri pribadi, dan lingkungan reaksi diri. Serta faktor lingkungan yang meliputi lingkungan fisik maupun sosial. Sehingga faktor yang mampu mempengaruhi regulasi diri dalam belajar yaitu efikasi diri dan lingkungan sosial teman sebaya.

Menurut Bandura (Khan, 2013) efikasi diri merupakan penilaian individu terhadap kemampuan diri dalam mengatur dan menjalankan perilaku yang digunakan dalam menyelesaikan tugas yang telah ditentukan. Hal ini akan berpengaruh pada proses pembelajaran dimana individu mampu mengontrol diri mereka dengan baik dalam proses belajar, sehingga mampu mencapai tujuan belajar. Individu dengan efikasi diri tinggi lebih termotivasi serta bekerja lebih baik dalam proses belajar (Chen \& Zimmerman, 2007)

Faktor lain yang dirasa memengaruhi belajar berdasar regulasi diri mahasiswa dalam proses belajar adalah dukungan sosial teman sebaya. Teman sebaya menjadikan individu lebih mampu mengontrol diri dalam proses belajar. Temuan menunjukkan bahwa dukungan sosial teman sebaya memainkan peran penting dalam membentuk sikap dan memandu individu dengan menunjukkan pendekatan pembelajaran yang lebih baik serta membantu dalam memahami proses belajar di perguruan tinggi (Hafzan, Abdullah, Husain, \& Abdullah, 2015).

Penelitian serupa yang dilakukan oleh Mulyana, Mujidin, \& Bashori (2015) mengenai peran motivasi belajar, efikasi diri dan dukungan sosial keluarga terhadap belajar berdasar regulasi diri menunjukkan bahwa peran motivasi belajar, dukungan sosial keluarga dan efikasi diri terhadap belajar berdasar regulasi diri pada siswa SMA.

Penelitian ini bertujuan untuk mengetahui peran efikasi diri dan dukungan sosial teman sebaya terhadap belajar berdasar regulasi diri pada mahasiswa Universitas Islam Sultan Agung Semarang. 


\section{LANDASAN TEORI}

Belajar berdasar regulasi diri mengasumsikan bahwa individu berpotensi memantau, mengarahkan dan mengontrol aspek-aspek baik kognisi, motivasi dan perilaku serta lingkungan (Pintrich, 2004).

Clark \& Zimmerman (2014) mengemukakan bahwa belajar berdasar regulasi diri dapat dipengaruhi oleh beberapa faktor, yaitu pribadi yang meliputi pengetahuan sebelumnya, keyakinan diri atau efikasi diri, tujuan atau niat, kemampuan dan proses afektif. Perilaku yang meliputi pengamatan diri, penilaian diri, reaksi diri, lingkungan dan perilaku pribadi. Serta lingkungan yang meliputi lingkungan fisik maupun sosial, seperti dukungan sosial.

Pintrich (1999) menjelaskan bahwa belajar berdasar regulasi diri mencakup dua aspek, yaitu motivasi dan strategi belajar. Motivasi terdiri dari komponen nilai, komponen penghargaan dan komponen afektif. Sedangkan strategi belajar terdiri dari strategi pembelajaran kognitif dan metakognitif yang meliputi pengulangan atau repetisi, perluasan, organisasi materi belajar, berpikir kritis, dan regulasi metakognitif. Serta strategi manajemen sumber daya yang meliputi pengelolaan dan pengendalikan waktu serta lingkungan belajar, regulasi usaha, mencari teman belajar seperti guru dan rekan kerja, serta penggunaan strategi pencarian bantuan.

Bandura (2012) menyatakan efikasi diri mempengaruhi seberapa baik orang memotivasi diri mereka sendiri dan tekun dalam menghadapi kesulitan melalui tujuan yang mereka tetapkan untuk diri sendiri. Efikasi diri adalah ketekunan pada perilaku dan tindakan yang ditentukan oleh penghakiman dan harapan mengenai kemampuan perilaku dan kesamaan kemampuan untuk berhasil mengatasi tuntutan dan tantangan lingkungan. Zimmerman (2000) mendefinisikan efikasi diri sebagai penilaian seseorang terhadap kemampuan dalam mengontrol serta melakukan kegiatan yang dibutuhkan dalam memperoleh tujuan spesifik. Efikasi diri mengacu pada kepercayaan diri individu untuk melakukan kesuksesan sepenuhnya dalam akademis yang menjadi prediktor hasil belajar (Hodges, 2008). Efikasi diri juga mempengaruhi tingkat usaha seseorang saat belajar dengan tugas yang sulit (Lunenburg, 2011).

Bandura (2012) menjelaskan bahwa efikasi diri dipengaruhi oleh beberapa faktor, yaitu pengalaman penguasaan, pengalaman perwakilan, persuasi sosial dan keadaan emosional.

a. Pengalaman Penguasaan

Pengalaman ini merupakan sumber yang paling berpengaruh terhadap keberhasilan individu. Keberhasilan akan membangun keyakinan yang kuat pada pribadi individu, sedangkan kegagalan akan melemahkan keyakinan individu.

b. Pengalaman Perwakilan

Merupakan suatu pengalaman yang diperoleh melalui pengamatan peristiwa yang dimodelkan oleh orang lain. Ketika individu melihat model yang mirip dengan dirinya berhasil akan meningkatkan keyakinan individu bahwa mereka juga memiliki kemampuan yang sebanding dengan model. Sebaliknya, mengamati kegagalan orang lain menurunkan keyakinan individu. Dampak pemodelan pada efikasi diri yang dirasakan sangat dipengaruhi oleh kesamaan persepsi terhadap model. Individu akan mencari model yang memiliki kompetensi dimana mereka bercitacita tinggi. Jika individu melihat modelnya berbeda dengan dirinya mereka sendiri efikasi diri tidak banyak dipengaruhi oleh pemodelan. 


\section{c. Persuasi Sosial}

Pendekatan ini diperoleh dan diperkuat melalui persuasi dari orang lain melalui perkataan. Kondisi ini adalah keyakinan individu kepada pemberi persuasi dalam mencapai keberhasilan. Persuasi negatif cenderung mengalahkan dan menurunkan efikasi diri individu.

d. Keadaan Emosional

Keadaan emosi akan berpengaruh pada efikasi diri. Perasaan hati yang baik meningkatkan efikasi diri dan perasaan hati yang tidak menyenangkan seperti emosi yang kuat, stres, dan kecemasan memberikan dampak negatif terhadap efikasi diri. Usaha untuk meningkatkan keyakinan diri adalah mengurangi reaksi stres dan mengubah emosi negatif mereka.

Bandura (1977) mengemukakan tiga aspek antara lain magnitude, strength dan generality. Magnitude berhubungan dengan tingkat kerumitan tugas. Dimana mengacu pada keyakinan individu dalam menyelesaikan tingkat kerumitan tugas, dari yang termudah, sedang dan tersulit. Streght berhubungan dengan ketahanan individu yang mengacu pada keyakinan individu tentang kesulitan tugas yang bisa diselesaikan. Semakin sulit tugas semakin rendah keyakinan yang dialami individu. Generality berkaitan bahwa keyakinan individu tidak dibatasi situasi. Dimana hal itu akan berlangsung dan berlaku dalam berbagai situasi.

Menurut Sarafino (2008) dukungan sosial sebagai rasa nyaman, keperdulian dan harga diri untuk membantu yang diperoleh orang lain dari kelompok lain. Dukungan sosial teman sebaya merupakan suatu pemberian yang diberikan yang mampu dirasakan seseorang pada waktu dibutuhkan dan seseorang tersebut merasa dianggap oleh lingkungannya oleh teman sebaya (Sari \& Indrawati, 2016). Sarafino (Setiawan \& Darminto, 2013) menjelaskan bahwa yang dukungan sosial teman sebaya dipengaruhi oleh beberapa fakor diantaranya yaitu Potensi penerima dukungan, Potensi penyedia dukungan, Komposisi dan struktur jaringan sosial

Sarafino (2008) mengungkapkan dukungan sosial terdiri dari beberapa aspek, diantaranya yaitu dukungan emosional, dukungan instrumental, dukungan informasi, dan dukungan persahabatan. Dukungan emosional merupakan dukungan yang meliputi ekspresi empati, perhatian dan kepedulian kepada orang yang memberi rasa nyaman, percaya diri, serta disayangi pada waktu dibutuhkan. Dukungan instrumental merupakan dukungan yang terlibat secara langsung. Dukungan informasi seperti memberi saran, petunjuk, atau umpan balik tentang bagaimana orang tersebut melakukannya. Dukungan Persahabatan merupakan dukungan yang meliputi ketersediaan waktu dalam menghabiskan secara bersama-sama dengan orang lain.

Berdasarkan uaraian di atas peneliti menyimpulkan bahwa ada peran efikasi diri dan dukungan sosial teman sebaya terhadap belajar berdasar regulasi diri pada mahasiswa Universitas Islam Sultan Agung Semarang.

\section{METODE PENELITIAN}

Populasi pada penelitian ini adalah mahasiswa Universitas Islam Sultan Agung Semarang yang berjumlah sekitar 12.740 . Teknik sampling yang digunakan dalam penelitian ini adalah simple random sampling dengan penentuan jumlah sampel dengan metode menurut Rao Purba dengan sampel pada penelitian ini berjumlah 150 mahasiswa.

Metode pengumpulan data berupa skala belajar berdasar regulasi diri yang terdiri dari 58 aitem dengan menggunakan aspek dari Pintrich (1999) yang terdiri dari dua sub skala yaitu motivasi dan 
strategi belajar dengan reliabilitas 0,941. Skala efikasi diri terdiri dari 28 aitem dengan menggunakan aspek dari Bandura (1977) terdiri dari aspek magnitude, strength dan generality dengan reliabilitas 0,896 . Skala dukungan sosial teman sebaya terdiri dari 37 aitem dengan menggunakan aspek dari Sarafino (2008) dengan reliabilitas 0,919.

Teknik analisis data yang digunakan dalam penelitian ini yaitu analisis regresi berganda untuk menguji hipotesis dan uji korelasi parsial untuk menguji hipotesis kedua dan ketiga. Penghitungan statistik dalam penelitian ini menggunakan bantuan SPSS (Statistical Product and Servise Solution) versi 19.

\section{HASIL PENELITIAN DAN PEMBAHASAN}

Sebelum melakukan uji hipotesis, dilakukan uji asumsi terlebih dahulu. Uji asumsi yang dilakukan dalam penelitian ini adalah uji normalitas, linieritas dan multikolinieritas. Hasil uji normalitas menggunakan One Sample Kolmogorov-smirnov Z. Hasil uji normalitas pada variabel belajar berdasar regulasi diri diperoleh nilai asymp sig 0,193 ( $p>0,05)$, variabel efikasi diri nilai asymp sig 0,162 $(p>0,05)$ dan variabel dukungan sosial teman sebaya nilai asymp sig $0,317(p>0,05)$. Hal ini berarti bahwa ketiga variabel tersebut memiliki distribusi normal.

Tabel 1. Hasil Uji Normalitas

\begin{tabular}{lllllll}
\hline Variabel & Mean & Std Deviasi & KS-Z & Sig & $\boldsymbol{p}$ & Keterangan \\
\hline Regulasi Diri & 173,61 & 12,296 & 1,081 & 0,193 & $>0,05$ & Normal \\
$\begin{array}{l}\text { Efikasi Diri } \\
\begin{array}{l}\text { Dukungan Sosial Teman } \\
\text { Sebaya }\end{array}\end{array}$ & 78,55 & 9,591 & 1,121 & 0,162 & $>0,05$ & Normal \\
\hline
\end{tabular}

Uji linieritas bertujuan untuk mengetahui suatu hubungan yang linier antara variabel satu dengan variabel lainnya. Uji linieritas yang dilakukan peneliti bertujuan untuk melihat signifikansi antara variabel yang teliti, sehingga variabel yang diteliti mampu diketahui apakah signifikan atau tidak.

Hasil uji linieritas variabel belajar berdasar regulasi diri dengan efikasi diri diperoleh $\mathrm{F}_{\text {linier }}=12,490$ dengan taraf signifikan $p=0,001(p<0,005)$. Sedangkan hasi uji linieritas variabel belajar berdasar regulasi diri dengan dukungan sosial teman sebaya dapat diperoleh $F_{\text {linier }}=12,212$ dengan taraf signifikan $p=0,001 \quad(p<0,005)$. Hasil tersebut menunjukkan bahwa diantara variabel bebas dan tergantung memiliki hubungan linier atau persamaan kedua variabel membentuk garis lurus.

Uji multikolineritas memiliki tujuan untuk menguji apakah model regresi ditemukan adanya korelasi antara variabel bebas. Model regresi yang baik seharusnya tidak terjadi korelasi antara variabel bebas. Metode pengujian model regresi dapat dilihat menggunakan nilai Variance Inflation Factor (VIP) yang lebih kecil dari 10 dan nilai Tolerance lebih dari 0,1 maka penelitian tidak terjadi multikolinearitas.

Hasil uji multikolinieritas diperoleh nilai Variance Inflation Factor (VIP) dari kedua variabel bebas yaitu efikasi diri dan dukungan sosial teman sebaya sebesar 1,270 dan nilai Tolerance sebesar 0,788, sehingga dapat dikatakan tidak terjadi multikolinieritas pada variabel bebas.

Hasil uji hipotesis menggunakan analisis regresi berganda diperoleh $\mathrm{R}$ sebesar 0,325 dan $\mathrm{F}_{\text {hitung }}$ sebesar 8,665 dengan taraf signifikansi 0,000 ( $p<0,05)$. Hasil ini menunjukkan bahwa efikasi diri dan dukungan sosial teman sebaya secara bersama-sama memiliki hubungan dengan belajar berdasar regulasi diri pada mahasiswa. Hasil analisis regresi nilai koefisien determinasi $R^{2}$ sebesar 0,105 atau 
$(10,5 \%)$ yang berarti secara bersama-sama variabel efikasi diri dan dukungan sosial teman sebaya mampu memberikan pengaruh sebesar 10,5 \% terhadap belajar berdasar regulasi diri pada mahasiswa. Model persamaan regresi linier adalah $Y=0,247 X 1+0,213 X 2+131,593$.

Berdasarkan penelitian ini terdapat dua faktor yang mempengaruhi belajar bedasar regulasi diri, yaitu efikasi diri dan dukungan sosial teman sebaya. Efikasi diri merupakan salah satu faktor yang mampu memengaruhi belajar berdasar regulasi diri. Individu dengan efikasi diri tinggi mampu menetapkan tujuan yang lebih ambisius, memilih tugas lebih banyak yang sulit dilakukan dan lebih terencana memilih strategi yang akan mereka lakukan untuk menyelesaikan tugas (Zimmerman \& Cleary, 2009). Variabel efikasi diri dan dukungan sosial teman sebaya secara bersamaan memiliki sumbangan efektif sebesar 10,5\% terhadap variabel belajar berdasar regulasi diri. Sedangkan 89,5\% dipengaruhi oleh faktor lain selain seperti tujuan belajar, kognitif dan motivasi.

Hasil korelasi parsial efikasi diri dengan belajar berdasar regulasi diri pada mahasiswa diperoleh nlai $r=0,178$ dengan taraf signifikansi $0,030(p<0,05)$. Hasil ini menunjukkan bahwa ada peran positif signifikan efikisi diri terhadap belajar berdasar regulasi diri. Semakin tinggi efikasi diri maka semakin tinggi belajar berdasar regulas diri dan sebaliknya.

Hasil analisis kategorisasi menunjukkan bahwa 76 subjek atau 50,67\% dari 150 subjek penelitian memiliki efikasi diri tinggi. Individu yang memiliki efikasi diri tinggi lebih mampu melakukan dan menyelesaikan semua tuntutan akademik dalam bentuk tugas dan ujian, serta mampu mengembangkan proses belajar berdasar regulasi diri (Dibenedetto \& Bembenutty, 2013).

Tabel 2. Kategorisasi Skor Skala Efikasi Diri

\begin{tabular}{llll}
\hline Norma & Kategorisasi & Frekuensi & Presentase \\
\hline $95,2<x \leq 112$ & Sangat Tinggi & 6 & $6 \%$ \\
$78,4<x \leq 95,2$ & Tinggi & 76 & $59,33 \%$ \\
$61,6<x \leq 78,4$ & Sedang & 64 & $34 \%$ \\
$44,8<x \leq 61,6$ & Rendah & 4 & $0,67 \%$ \\
$28<x \leq 44,8$ & Sangat Rendah & 0 & $0 \%$ \\
Jumlah & & 150 & $100 \%$ \\
\hline
\end{tabular}

Deskipsi skor belajar berdasar regulasi diri berdasarkan hasil penelitian empirik diperoleh skor minimum sebesar 149, skor maksimum sebesar 200, mean sebesar 173,61 dan standar deviasi sebesar 12,296.

Tabel 3. Norma Kategorisasi Skor Skala Belajar Berdasar Regulasi Diri

\begin{tabular}{llll}
\hline Norma & Kategorisasi & Frekuensi & Persentase \\
\hline $197,2<x \leq 232$ & Sangat Tinggi & 0 & $0 \%$ \\
$162,4<x \leq 197,2$ & Tinggi & 127 & $84,67 \%$ \\
$127,6<x \leq 162,4$ & Sedang & 23 & $15,33 \%$ \\
$92,8<x \leq 127,6$ & Rendah & 0 & $0 \%$ \\
$58 \quad<x \leq 92,8$ & Sangat Rendah & 0 & $0 \%$ \\
Jumlah & & 150 & $100 \%$ \\
\hline
\end{tabular}

Berdasarkan tabel di atas, dapat diketahui bahwa rentang skor terletak pada kategorisasi tinggi yang berdasarkan mean empirik, artinya sebagian besar subjek dalam penelitian ini memiliki regulasi diri dalam belajar yang baik.

Faktor lain yang berpengaruh terhadap belajar berdasar regulasi diri yaitu dukungan sosial teman sebaya. Dukungan sosial teman sebaya yang tinggi akan meningkatkan belajar berdasar regulasi diri. 
Teman sebaya biasanya membentuk kelompok belajar, memantau teman atau membantu individu ketika mengalami kesulitan (Dennis, Phinney, \& Chuateco, 2005).

Hasil analisis korelasi dukungan sosial teman sebaya dengan belajar berdasar regulasi diri pada mahasiswa diperoleh nila $r=0173$ dengan taraf signifikansi 0,035 $(p<0,05)$. Hasil ini menunjukkan bahwa ada peran positif signifikan dukungan sosial teman sebaya terhadap belajar berdasar regulasi diri. Semakin tinggi dukungan sosial teman sebaya, maka semakin tinggi belajar berdasar regulasi diri dan sebaliknya.

Hasil analisis kategorisasi menunjukkan bahwa 89 subjek atau 59,33\% dari 150 . Hal ini menunjukkan bahwa subjek sudah memperoleh dukungan sosial dari teman sebaya yang cukup tinggi. Dukungan sosial dari teman sebaya yang tinggi membantu mahasiswa dalam memperoleh informasi dan menginformasikan mahasiswa tentang bagaimana mengontrol proses belajarnya, sehingga regulasi diri pada mahasiswa dapat tercapai (Labuhn et al., 2010).

\section{KESIMPULAN}

Berdasarkan hasil penelitian yang telah dilakukan, dapat ditarik kesimpulan bahwa:

1. Ada peran positif efikasi diri dan dukungan sosial teman sebaya terhadap belajar berdasar regulasi diri pada mahasiswa Universitas Islam Sultan Agung Semarang secara bersama-sama.

2. Ada peran positif efikasi diri terhadap belajar berdasar regulasi diri. Serta ada peran positif dukungan sosial teman sebaya terhadap belajar berdasar regulasi diri.

\section{SARAN}

a. Bagi mahasiswa

Mempertahankan dan meningkatkan kemampuan belajar berdasar regulasi diri, efikasi diri dan dukungan sosial teman sebaya.

b. Bagi peneliti selajanutnya

Bagi penelitian selanjutnya, disarankan melihat faktor-faktor lain yang dapat dijadikan sebagai variabel bebas seperti tujuan belajar, kognitif dan motivasi.

\section{DAFTAR PUSTAKA}

Bandura, A. (1977). Self-efficacy: toward a unifying theory of behavioral change. Psychological Review, 84(2), 191-215.

Bandura, A. (2012). On the functional properties of perceived self-efficacy revisited. Journal of Management, 38(1), 9-44. https://doi.org/10.1177/0149206311410606

Chen, P., \& Zimmerman, B. (2007). A cross-national comparison study on the accuracy of self-efficacy beliefs of middle- school mathematics students. The Hournal of Experimental Education, 75(3), 221-244. https://doi.org/10.3200/JEXE.75.3.221-244

Clark, N. M., \& Zimmerman, B. J. (2014). A social cognitive view of self-regulated learning about health. Health Education \& Behavior, 41(5), 485-491. https://doi.org/10.1093/her/5.3.371

60 
Peran Efikasi Diri dan Dukungan Sosial Teman Sebaya Terhadap Belajar Berdasar Regulasi Diri Pada Mahasiswa

Dennis, jessica M., Phinney, J. S., \& Chuateco, L. I. (2005). The role of motivation, parental support, and peer support in the academic success of ethnic minority first-generation college students. Journal of College Student Development, 46(3), 223-236. https://doi.org/10.1353/csd.2005.0023

Dibenedetto, M. K., \& Bembenutty, H. (2013). Within the pipeline : self-regulated learning, selfefficacy, and socialization among college students in science courses. Learning and Individual Differences, (23), 218-224.

Effeney, G., Carroll, A., \& Bahr, N. (2013). Self-Regulated Learning : Key strategies and their sources in a sample of adolescent males, $13,58-74$.

Gottlieb, B. H., \& Bergen, A. E. (2010). Social support concepts and measures. Journal of Psychosomatic Research, 69(5), 511-520. https://doi.org/10.1016/j.jpsychores.2009.10.001

Hafzan, A., Abdullah, A. N., Husain, K., \& Abdullah, N. (2015). The role of learning approaches as mediator between peer social support and self regulated learning among enginee. Asian Social Science, 11(17), 67-73. https://doi.org/10.5539/ass.v11n17p67

Khan, M. (2013). Academic self-efficacy, coping, and academic performance in college. Internasional Journal of Undergraduate Research and Creative Activities, 5(October), 4. https://doi.org/tttp://dx.doi.org/10.7710/2168-0620.1006

Labuhn, A. S., Zimmerman, B. J., \& Hasselhorn, M. (2010). Enhancing students' Self-regulation and mathematics performance: the influence of feedback and self-evaluative standards. Matacognition Learning, 5, 173-194. https://doi.org/10.1007/s11409-010-9056-2

Mulyana, E., Mujidin, \& Bashori, K. (2015). Peran motivasi belajar, self-efficacy, dan dukungan sosial keluarga terhadap self-regulated learning pada siswa. Psikopedagogia, 4(1), 165-173.

Pintrich, P. R. (2004). A conceptual framework for assessing motivation and self-regulated learning in college students. Educational Psychology Review, 16(4), 385-407.

Sarafino, E. P. (2008). Health psychology biopsychosocial interactions (6th ed.). United States: John Willey \& Sons, Inc.

Sari, P. K. P., \& Indrawati, E. S. (2016). Hubungan antara Dukungan Sosial Teman Sebaya dengan Resiliensi Akademik pada Mahasiswa Tingkat Akhir Jurusan x Fakultas Teknik Universitas Diponegoro, 5(April), 177-182.

Setiawan, A. I., \& Darminto, E. (2013). Pengaruh dukungan sosial terhadap stres kerja pada karyawan, $1(3)$.

Zimmerman, B. J. (2000). Self-Efficacy : an essential motive to learn. Contemporary Educational Psychology, 25, 82-91. https://doi.org/10.1006/ceps.1999.1016 
Zimmerman, B. J. (2008). Investigating self-regulation and motivation: historical background, methodological developments, and future prospects. American Educational Research, 45(1), 166-183. https://doi.org/10.3102/0002831207312909

Zimmerman, B. J. (2013). From cognitive modeling to self-regulation: A social cognitive career path. Educational Psychologist, 48(3), 135-147. https://doi.org/10.1080/00461520.2013.794676

Zimmerman, B. J., \& Cleary, T. J. (2009). Motives to self-regulate learning: a social-cognitive account. 